How to Cite

Ghosh, C. (2018). Evaluation of new marketing strategy of selected home appliances. International Journal of Business,

Economics \& Management, 1(1), 22-25. https://doi.org/10.31295/ijbem.v1n1.24

\title{
Evaluation of New Marketing Strategy of Selected Home Appliances
}

\author{
Chinmoy Ghosh \\ East Calcutta girls' college, Lake Town, India \\ Email: chin.lord@gmail.com
}

\begin{abstract}
Strategy generally known as a coherent set of actions aimed at gaining a sustainable advantage over competition improving position vis-à-vis customers or allocating resources. Tactical planning refers to short-range planning that is oriented towards operations and is concerned with specific and short-range details. Strategy, includes the determination and evaluation of alternatives paths to an already established mission or objectives and eventually choice of the alternatives to be adopted. Poke Strategy, includes the four ingredients such as Price, offers, brand, competitive marketing strategies. The struggle for existence and growth is indeed very hard for firms in a competitive environment. The new strategy (poke) will help the enterprise to cope up with the market competition. Tow matrix prove the existence of the new marketing strategy poke.

Keywords---home appliances, new marketing strategy.
\end{abstract}

\section{Introduction}

Strategy generally known as a coherent set of actions aimed at gaining a sustainable advantage over competition improving position vis-à-vis customers or allocating resources. Tactical planning refers to short-range planning that is oriented towards operations and is concerned with specific and short-range details. Strategy, includes the determination and evaluation of alternatives paths to an already established mission or objectives and eventually choice of the alternatives to be adopted.

The struggle for existence and growth is indeed very hard for firms in a competitive environment. As the environment changes their vision and objectives, structure, portfolio of business, market and competitive strategies. The liberalisation has, however, vastly changed the scenario. Strategy relates three basic principles-

a) Wider ramification

b) Long time perspective

c) Critical resources towards perceived opportunities

In our study we try to evaluate the SWOT analysis of a new marketing strategy POKE (SHOCK-KNOCK).

Table 1

New marketing strategy POKE (SHOCK-KNOCK)

\begin{tabular}{lll}
\hline Strength/weakness & Opportunity/threat & Strategy \\
\hline Gaps in the product mix & $\begin{array}{l}\text { A competitors firm whose } \\
\text { product items can fill the gaps } \\
\text { is for sale }\end{array}$ & Acquire the competitors firm \\
$\begin{array}{l}\text { Gas technology and production } \\
\text { capability, low production } \\
\text { costs, but no capability }\end{array}$ & & $\begin{array}{l}\text { Strategic alliance with } \\
\text { different firms having } \\
\text { marketing muscle }\end{array}$ \\
\hline
\end{tabular}

ISSN 2632-9476

Received Jan 10, 2018 / Accepted Jun 20, 2018 / Published Jul 05, 2018 
Objective of the study

Does poke Strategy, includes the determination and evaluation of alternatives paths of strategy formulation process?

\section{Research Method}

The TOWS Matrix propounded by Heinz Weihirich, is an important strategy formulation matching tool.

Table 2

Strategy formulation matching tool

\begin{tabular}{|c|c|c|}
\hline $\begin{array}{l}\text { EXTERNAL } \\
\text { FACTORS }\end{array}$ & $\begin{array}{c}\text { INTERNAL STRENGTHS } \\
(\mathrm{S})\end{array}$ & $\begin{array}{c}\text { INTERNAL WEAKNESS } \\
\text { (W) }\end{array}$ \\
\hline EXTERNAL & SO (Maxi-Maxi) & WO(Mini-Max) \\
\hline OPPERTUNITIES & Strategy & Strategy \\
\hline$(\mathrm{O})$ & $\begin{array}{l}\text { (Maximum strengths and } \\
\text { opportunities) }\end{array}$ & $\begin{array}{l}\text { (Minimise weakness and } \\
\text { maximise opportunities) }\end{array}$ \\
\hline EXTERNAL & $\mathbf{S T}($ Maxi-Mini) & $\mathbf{W T}(M i n i-M i n i)$ \\
\hline THREATES & strategy & Strategy \\
\hline$(\mathrm{T})$ & $\begin{array}{l}\text { (Maximum strengths and } \\
\text { minimise threats) }\end{array}$ & $\begin{array}{l}\text { (Minimise weaknesses and } \\
\text { threats) }\end{array}$ \\
\hline
\end{tabular}

Research methodology

a) Frame questioner

b) Sample size 100 ( SIMPLE RANDOM SAMPLE)

c) Analyse samples by graph and tow matrix

The study is exploratory type. We try to explore the area of marketing strategies generally used by the home appliances company.

Framing questioner absolutely close ended type (tick mark)

\section{Questioner}

1. When you purchase home appliances which will knock your mind?

a. Price b. design c. None

2. Which will you purchase company brand or product?

a. Brand b. product c. don't know

3. Offers provided by companies are shocking to you?
a. Yes
b. no c. don't know

4. Competitive marketing strategies does any influencing nature when you selecting product?

a. Yes b. no c. don't know

5. How competitive marketing strategy influence you to fulfil your need?
a. Yes b.no c. don't know

\section{Results and Analysis}

Table 3

List of Question

\begin{tabular}{llll}
\hline QUESTION NO. & OPTION-1 & OPTION-2 & OPTION-3 \\
\hline 1. & 60 & 28 & 12 \\
2. & 55 & 22 & 23 \\
3. & 69 & 18 & 13 \\
4. & 52 & 20 & 28 \\
5. & 52 & 20 & 28 \\
\hline
\end{tabular}




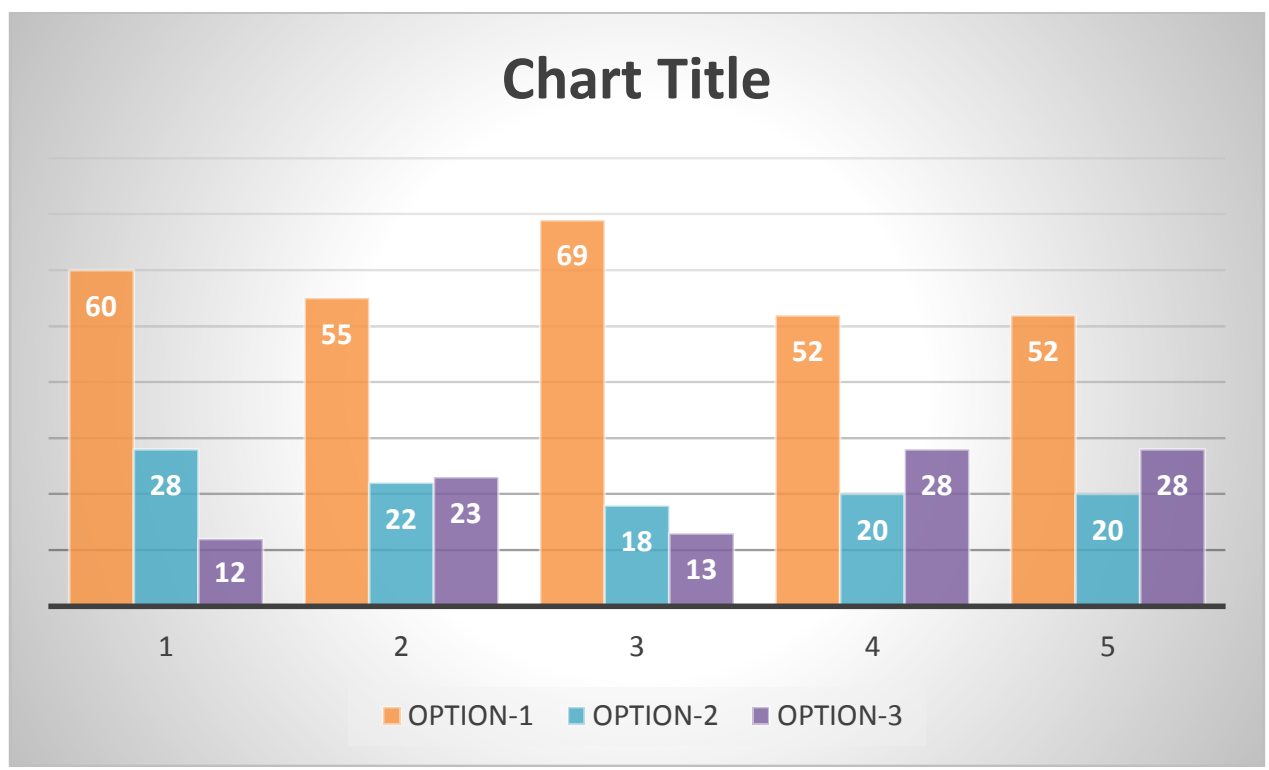

Figure 1. Options title

According to the graphical analysis the factors affecting the formulation of new marketing strategy poke mostly are Price, Brand, Offers, and competitive marketing Strategies.

Analysis of POKE strategy by TOWS Matrix

Table 4

TOWS Matrix

\begin{tabular}{|c|l|l|}
\hline $\begin{array}{c}\text { EXTARNAL } \\
\text { FACTORS } \\
\text { INTERNAL } \\
\text { FACTORS }\end{array}$ & \multicolumn{1}{|c|}{$\begin{array}{c}\text { INTERNAL STRENGTHS } \\
(\mathrm{S})\end{array}$} & \multicolumn{1}{|c|}{$\begin{array}{l}\text { INTERNAL WEAKNESS } \\
(\mathrm{W})\end{array}$} \\
\hline $\begin{array}{c}\text { EXTERNAL } \\
\text { OPPERTUNITES } \\
(\mathrm{O})\end{array}$ & $\begin{array}{l}\text { Price }(60) \\
\text { Maxi-maxi }\end{array}$ & $\begin{array}{l}\text { Offers }(69) \\
\text { Mini-max }\end{array}$ \\
\hline $\begin{array}{c}\text { EXTERNAL } \\
\text { THREATES } \\
(\mathrm{T})\end{array}$ & $\begin{array}{l}\text { Brand (55) } \\
\text { Maxi-min }\end{array}$ & $\begin{array}{l}\text { Competitive Marketing } \\
\text { strategies (52) } \\
\text { Mini-mini }\end{array}$ \\
\hline
\end{tabular}

According to the TOW matrix analysis we can say that -

Price + offers + brand + competitive marketing strategies $=$ poke $($ shock - knock $)$ strategy

\section{Conclusion}

Poke Strategy, includes the four ingredients such as Price, offers, brand, competitive marketing strategies. The struggle for existence and growth is indeed very hard for firms in a competitive environment. The new strategy (poke) will help the enterprise to cope up with the market competition. Tow matrix prove the existence of the new marketing strategy poke.

\section{Acknowledgements}

The author would like to thank the editor for their valuable time and advice. 


\section{References}

Cespedes, F. V. (1995). Concurrent marketing: Integrating product, sales, and service. Harvard Business Press.

Ghosh, C. (2017). A Study on-Evaluating Marketing Strategies Adopted by Home Appliance for Economic Development in India. International Journal of Social Sciences and Humanities (IJSSH), 1(1), 9-15.

Ifeanyichukwu, C. D., \& Peter, A. (2018). The Role of Sensory Marketing in Achieving Customer Patronage in Fast Food Restaurants in Awka. International Research Journal of Management, IT and Social Sciences (IRJMIS), 5(2), 155-163.

Kotler, P. (1999). How to create, win and dominate markets. New York: A Division of Simon \& Schuster Inc.

Kotler, P., Saliba, S., \& Wrenn, B. (1991). Marketing management: Analysis, planning, and control: Instructor's Manual. Prentice-hall.

Mora, M. M., Espinosa, M. R., \& Delgado, M. R. (2018). Approach of Processes for the Distribution of Economic Resources in Public University of Ecuador. International Research Journal of Management, IT and Social Sciences (IRJMIS), 5(1), 25-35.

Ogunsiji, A. S., \& Ladanu, W. K. (2017). A Theoretical Study of Performance Measures in the Strategic and Corporate Entrepreneurships of Firms. International Journal of Physical Sciences and Engineering (IJPSE), 1(1), 72-80.

Tripathy, M. (2018). Building quality teamwork to achieve excellence in business organizations. International Research Journal of Management, IT and Social Sciences (IRJMIS), 5(3), 1-7.

Wayland, R. E., \& Cole, P. M. (1997). Customer connections: New strategies for growth. Harvard Business Press. 